
internationales

vol. $22-n^{\circ} 1 \mid 2006$

Dossier "Figures et expériences diasporiques"

\title{
Taiwan's Mainlanders: A Diasporic Identity in Construction
}

Les Chinois de Taiwan : la construction d'une identité diasporique

Los chinos de Taiwán: la construcción de una identidad "diáspórica"

\section{Simon Scott}

\section{(2) OpenEdition}

Electronic version

URL: https://journals.openedition.org/remi/2715

DOI: $10.4000 /$ remi.2715

ISSN: $1777-5418$

Publisher

Université de Poitiers

Printed version

Date of publication: 1 March 2006

Number of pages: 87-106

ISBN: 2-911627-41-5

ISSN: 0765-0752

\section{Electronic reference}

Simon Scott, "Taiwan's Mainlanders: A Diasporic Identity in Construction", Revue européenne des migrations internationales [Online], vol. 22 - $\mathrm{n}^{\circ} 1$ | 2006, Online since 01 April 2009, connection on 14 April 2022. URL: http://journals.openedition.org/remi/2715 ; DOI: https://doi.org/10.4000/remi.2715

This text was automatically generated on 14 April 2022.

(c) Université de Poitiers 


\title{
Taiwan's Mainlanders: A Diasporic Identity in Construction
}

\author{
Les Chinois de Taiwan : la construction d'une identité diasporique \\ Los chinos de Taiwán: la construcción de una identidad "diáspórica"
}

\section{Simon Scott}

\section{The old is dying, and the new cannot be born; in this interregnum there arise a great diversity of morbid symptoms \\ (Antonio Gramsci, cited in Crapanzano, 1986: 47).}

1 Diaspora is a relatively new concept to the study of Taiwan; but is nonetheless a useful conceptual tool in understanding shifting ethnic relations during the island nation's tumultuous and yet unfinished process of decolonization. Taiwanese political discourse of the past two decades has constructed Taiwanese society as comprised of four ethnic groups. These are the indigenous peoples of Austronesian descent (approximately $2 \%$ of the population), whose presence on Taiwan dates back over 6000 years; the Hoklo (72\%), whose paternal ancestors started arriving from Fujian Province of China during Dutch occupation of part of Taiwan in the 1600s; the Hakka (13\%) whose ancestors came from Guangdong Province mostly in the $18^{\text {th }}$ and $19^{\text {th }}$ centuries, and finally the Mainlanders (13\%), who arrived with Chiang Kai-shek after the conclusion of the Second World War in 1945 (Corcuff, 2002: 163).

2 Mainlanders, the group under discussion in this article, are called waishengren in Chinese or goa-seng-lang in Taiwanese, both meaning "people from outside the province." This ethnic identity, determined by an imaginary province of origin that some individuals had never even seen, was even a legal category on official documents until 1992. The process by which waishengren and their Other (benshengren or "people of the province") became social categories of ethnicity demonstrate clearly how legal categories metamorphose into ethnic categories in ways unimagined by their creators (Corcuff, 2002: 171). 
3 As Taiwanese nationalism gains ascendancy over Chinese nationalism in Taiwanese society, Mainlanders are increasingly adopting a diasporic identity as Chinese in Taiwan (Chang, 2005). The labels and boundaries between ethnic groups are clearly related to the construction of a national identity on Taiwan; and need to be interrogated for the lessons they can teach us about the relationship between migration, decolonization, diasporas, and nationalism. Although these processes of national fragmentation and ethnicisation are part of the global Zeitgeist of our times (Elbaz and Helly, 1995), the case of Taiwan is particularly interesting because the boundaries between diasporas and the nation have changed so rapidly.

4 In order to understand the relationship between diasporic imaginations and nationalism in this fascinating case study, it is important to ask the following questions: To what extent do Taiwan's Mainlanders constitute a diasporic community? How do discourses of Chinese diaspora in Taiwan contrast with, or articulate with, coexisting discourses of colonialism and resistance, as well as discourses of republican or multicultural citizenship? What do these competing discourses say about how the larger meaning of diaspora?

\section{Diaspora as a form of ethnic identity}

5 In anthropology, constructionist approaches to ethnicity are based largely on the insights of Norwegian anthropologist Fredrik Barth who argued that ethnic groups are not objective entities, but are rather formed through boundaries they form with others in specific historical circumstances (Barth, 1969). Since diasporas constitute one particular variety of ethnic group, James Clifford similarly used the term diaspora as "a signifier, not simply of transnationality and movement, but of political struggles to define the local, as distinctive community, in historical contexts of displacement" (Clifford, 1994: 308). Diaspora, argues Clifford, exists largely in tension with nationalist and autochtonous identity formations in which different groups use different criteria to claim "native" status on the same territory.

6 Within this larger political context, diasporas often share a number of broad characteristics. Safran defined diasporas as "expatriate minority communities" characterized by an experience of dispersal from their homeland, collective memories of that homeland, a belief that they are not accepted in their new land, a desire for return, support of their homeland, and a collective identity constructed around their place of origin (Safran, 1991: 83-84). Diasporic identities are closely related to national identities, as they define who belongs to, but also whom is excluded from a given nation as "imagined community" (Anderson, 1991). Diasporas are non-native in relationship to ethnic nationalisms, but can be more easily absorbed into civic nationalisms. As with national borders, therefore, the boundaries between diaspora and nativist identities are often contested from both sides.

Diaspora studies have usually focused on immigrant communities. The Jews constitute the paradigmatic case of diaspora due to their dispersal throughout the world; strong collective identity; ritualized memories of the lost homeland; and a desire for spiritual, if not physical, return to Israel. Armenians, Africans throughout the North Atlantic, and immigrant Asians are also frequently studied as diasporas. Less commonly studied as diasporas are those peoples, such as Europeans in North America or Africa, who 
dispersed to other parts of the world as part of a colonizing project (Schnapper, 2001: 11).

8 In the process of decolonization, however, diaspora becomes relevant to those situations, especially for members of communities who have stayed behind rather than returning to their places of origin. Yet in order to avoid an overuse of the concept of diaspora, it is important to limit it to cases in which there is some institutionalized exchange between the home and diaspora communities, as well as at least an imaginary desire to "return" (Schapper, 2001: 31). Without those two elements, the English and the French of Canada do not constitute diaspora communities, but, as argued below, the Mainlanders of Taiwan do. In colonial and post-colonial situations, the formation of diaspora identity constitutes an unfinished process of struggle and negotiation in which past colonialism shapes contemporary struggles. The postcolonial construction of such diasporas is as important in the study of Taiwan's Mainlanders as it is for whites in South Africa.

\section{Mainlander ethnic identity}

9 Although most of the anthropological literature on Taiwan since the 1970s has subsumed Mainlanders and Native Taiwanese under the general rubric of "Chinese culture," the ethnic boundaries between them have also been recognized as salient, especially the boundary constructed between Mainlanders and "Native Taiwanese," referring to both the Hoklo and the Hakka. Although the boundaries between these groups are also a product of Chinese Nationalist rule (see below), they have been increasing reinforced in public discourse since the gradual democratization and decolonization of Taiwan that began in the 1980s.

Group identities constructed around the four ethnicities of Mainlanders, Hakka, Hoklo and Aboriginal have been particularly prone to mobilization during political rallies and at election time. As the Native Taiwanese gained power in Taiwan, the Mainlanders have lost many of the privileges they enjoyed in the past. In this context, they fear being classified as members of an ethnic minority or political scapegoats. Many Mainlanders feel threatened by this shift in political power and by the ethnic discourse that has come with it; and thus believe rumours that Native Taiwanese have even shouted out "Mainland pigs go home!" at political rallies. Yet in a democratic country where alternative nationalisms can be freely expressed and contested, it is difficult to return to the old discourse that "we are all Chinese"- especially since in practice the groups have never been equal. Instead, Mainlanders seem to be reluctantly constructing a new diasporic identity to negotiate a new place a Taiwan that is going through a process of decolonization comparable to that of South Africa (Wu, 2002).

11 Mainlander dis-ease with Taiwanese nationalism is readily apparent in Taiwan. After the 2004 presidential elections, for example, when Native Taiwanese candidate Chen Shui-bian won the presidency for the second time, a heavily-accented Mainlander taxi driver explained to me that the results would surely be disastrous. He argued that Chen's Taiwanese nationalism was dangerous and could easily lead to violence against "foreigners" like himself. When I argued that surely all people who carry Republic of China passports are Taiwanese, he referred to the Native Taiwanese saying, "They don't recognize that. They think we Mainlanders are not Taiwanese. To them, we are Chinese. We are foreigners." He broke into tears as he contemplated on the possibility that 
political change might bring about an official declaration of Taiwanese independence and thus the end of the Republic of China on Taiwan. Conversations such as this, which reflect Mainlander discomfort with political developments in Taiwan, provide a useful point of departure for the study of the Mainlander diaspora as a new form of ethnic identity in the country.

\section{The historical genesis of Mainlander identity on Taiwan}

12 Due to their phenotypical similarities, the differences between Mainlanders and Native Taiwanese seem small compared to those between "black" and "white" Africans unless one keeps in mind that all ethnicities are relationships of power rather than essentialized objects in themselves. Not unlike different ethnic groups in Africa, the boundary between Mainlanders and Native Taiwanese was formed out of conflict, violence and oppression. After Japan's defeat at the conclusion of the Second World War, the Allied Forces under General MacArthur transferred the Japanese colony of Taiwan to the administration of the Republic of China without consulting the local people about their future.

Those people already living on Taiwan, the indigenous Austronesian tribes and the numerical majority of "Native Taiwanese", were soon faced with the problem of accommodating newcomers from China. Due to historical circumstances, the social distance between the groups was large. The indigenous peoples spoke Japanese and a variety of Austronesian languages. Native Taiwanese spoke Japanese and Hakka or Hoklo, the latter known now as "Taiwanese", while the Mainlanders spoke Mandarin Chinese with various degrees of proficiency and various Chinese dialects. Although it is often claimed that Hakka and Hoklo (Taiwanese) are merely dialects of Chinese, the difference between Taiwanese and Mandarin is as different as that between Dutch (or Afrikaaner) and English. The Austronesian languages are not related to Chinese at all; but are instead related to other Pacific islander languages such as Maori, Hawaiian and Chamorro.

Between 1945 and 1949, several waves of people started arriving from China to Taiwan, including members of the new military administration under Chen Yi, those sent by the Chinese Nationalist Party (KMT) to establish civil and military authority, and Chinese civilians looking for job opportunities. After the Chinese Revolution of 1949, the Chinese Nationalist Party was forced to retreat to Taiwan, bringing with them more military personnel and an unknown number of civilian refugees. They depended on the Nationalist government for housing and living; and initially expected that their return to China would be imminent. Not expecting to settle down permanently in Taiwan, they identified strongly with the Chinese Nationalist Party, with their places of origin in China, and felt a strong sense of cultural superiority over the Taiwanese (Corcuff, 2002: 172-174).

Relations between the two groups were particularly strained in the aftermath of the tragic events of the 1940s. After the Republic of China arrived on Taiwan in 1945, the new government began by confiscating property belonging to the Japanese colonial government, Taiwanese enterprises and even individuals. They appropriated large amounts of local commodities - including basic needs such as sugar, salt and rice - to be shipped to the mainland; a situation that led to critical shortages and inflation in 
Taiwan (Morris, 2004: 20). Chinese soldiers terrorized the local population by stealing, looting and raping. Resentment led to the Taiwanese making unfavorable comparisons with the Japanese, saying that the takeover was a situation of "the dogs leaving and the pigs coming."

Disaster struck on the evening of February 27, 1947, when agents of the Taipei City Monopoly Board tried to confiscate the contraband cigarettes that a woman peddler was selling on the street. When she was injured in the ensuing scuffle, neighbors tried to defend her and a riot broke out, leading to the police shooting of a bystander. As news of the event spread throughout Taiwan, local leaders set up "February 28 Resolution Committees" to demand investigation of the incident, democratic and economic reforms, and limited self-rule. Governor Chen Yi promised to negotiate, but actually requested military reinforcement from China. When troops arrived, they first killed Taiwanese indiscriminately on the streets and then rounded up opposition leaders for execution. The exact casualty numbers are still unknown, but estimates range from a few hundred to more than 20000 . Martial law was imposed afterwards and would last forty years - the longest period of martial law in human history. Those years are now known as the time of "white terror."

It was in this difficult transition from Japanese to ROC rule that the Mainlanders began to be perceived - and to perceive themselves - as a distinct ethnic group. As Corcuff wrote:

The people associated with the geographical entity of Mainland China were also associated with a regime, an army, a police force, but more important still, an ideology, a project for winning back the lost continent... A new ethnic category was in the process of being born (Corcuff, 2002: 166).

In many ways, the Mainlanders of this generation already resembled diasporas as defined by Safran as expatriate minority communities characterized by memories of their homeland, a desire to return, and a collective identity constructed around it. The crucial difference between the first generation of Mainlanders on Taiwan and immigrant diasporas, however, was that the Mainlanders held the reins of power in Taiwan. Unable to return to China, at least in the short run, they committed themselves to the Chinese Nationalist Party and to reshaping Taiwan to their own image as the Republic of China. Rather than a relationship of immigrants to a host majority, it was a relationship of colonial domination.

\section{Colonizing Taiwan}

19 Colonialism, in the sense of postmodern anthropology, is many things at once: an ideological project and an institutional order, a process and an existential state-ofmind, but above all, a construction and negotiation of difference in situations of unequal power (Comaroff, 1998). In the 1960s, when decolonization was beginning in Africa and the memories of February 28, 1947, were still fresh in the memories of the Taiwanese, colonialism was clearly the existential state-of-mind of most Taiwanese:

Today most of the 10,000,000 Formosans look upon the nearly 2000000 mainlanders who fled to Formosa with the collapse of Kuomintang rule as foreign overlords and describe the Chinese nationalist regime as a colonial tyranny far more oppressive than the former Japanese rule. That the overwhelming majority of Formosans favour the establishment of an independent Formosan state, without ties to mainland China and, preferably, without the presence of Mainlanders, is a fact that can no longer be ignored (Meisner, 1963: 91). 
the early decades of Chinese Nationalist rule, just as under Japanese administration, the government discriminated against Native Taiwanese in favor of the colonizers. This systematic discrimination fostered a sense of ethnic identity among both Mainlanders and Native Taiwanese (Gates, 1981: 261). In addition to political domination, the government owned or controlled most of the larger industries and commercial enterprises, the transportation system and public utilities. In employment, they systematically discriminated against Native Taiwanese employees, often blocking hiring or promotion with the excuse that the Taiwanese did not speak Mandarin well enough. In the school system and military, as well, Taiwanese were subordinated to Mainlanders. The Chinese Nationalist state, not to mention local officials and police, also used their political domination to extract taxes, fees and levies for political campaigns from Native Taiwanese farmers. All of these practices kept alive a feeling of antagonism towards Mainlanders (Meisner, 1963: 100-101). Anthropologist Hill Gates argued the construction of ethnic difference actually benefited both ethnic groups and the government. In the early decades of Chinese Nationalist rule, a separation of Mainlander soldiers and the Taiwanese lower class helped maintain political stability and control the population (Gates, 1981: 269).

chltural domination of the Chinese Nationalists over Taiwan was firmly implanted by the 1960 s in processes well known to scholars of the cultural dimensions of colonization (e.g. Comaroff, 1989, Comaroff and Comaroff, 1989, Cooper and Stoler, 1989, Dirks, 1992). Chinese Nationalist education and media denigrated Taiwanese local culture, including life-styles, cuisine, and religion as backwards and rural. Members of both groups internalized those values (Gates, 1981: 253). In order to force the Taiwanese to learn Mandarin Chinese, children were often beaten, humiliated, or fined for speaking Japanese, Taiwanese, or even aboriginal languages in school (Morris, 2004: 25). The Chinese Nationalist party-state took all possible measures to implant their symbolic rule over Taiwan, tearing down Shinto shrines and other Japanese monuments, renaming streets after place names in China, and erecting statues of both Sun Yat-sen and Chiang Kai-shek all over the island. Like colonial regimes in Africa, the Chinese Nationalists had to fabricate what Comaroff (1998: 329) called "an entire spacetime world" with its logic insinuated into the most mundane practices of citizens now re-membered as Chinese.

The educational system taught children that China represents all that is modern and good, and that they should be proud to be Chinese rather than foreign, Japanese, or even locally Taiwanese (Simon, 2005: 35-36). Beginning in 1968, Chinese Nationalists with missionary zeal even brought adult women into "Mothers' workshops" on Confucian ethics, emphasizing that Taiwanese women are traditional Chinese wives and mothers who should thus work for free in their husbands' subcontracting workshops (Greenhalgh, 1994; Hsiung, 1996). Taiwanese who resisted sinicization, and especially those who advocated the independence of Taiwan from the Republic of China, faced imprisonment or worse. Some political prisoners were summarily executed (Arrigo, 1998).

23 As so often happens in colonial situations (Fanon, 1967), many Taiwanese internalized the idea that the language and cultural markers of the colonizers were more prestigious than those of the local people. Under the sway of colonial mentality, Peking opera was elevated to high culture, while local opera and puppet shows were denigrated as high class. The National Palace Museum in Taipei highlighted the

Revue européenne des migrations internationales, vol. 22 - $n^{\circ} 1$ | 2006 
pageantry of Chinese history, while younger generations of Taiwanese learned nothing about their island's past. Socially, Native Taiwanese often worked as servants for Mainlanders, but even the poorest Mainlanders would not work as servants for the Native Taiwanese (Meisner, 1963: 101). The prestige of the Chinese was even reflected through hypergamy, as there was a trend for Native Taiwanese women to marry Mainlander men but not for Mainlander women to marry Taiwanese (Meisner, 1963: 103). A generation later, the children of such couples still tend to self-identify as Chinese Mainlanders rather than as Taiwanese. In the 1970s, however, the dialectic of history began to work in another direction as the experience of subordination led to counter-hegemonic movement.

\section{Crisis, democratization, and the taiwanization of identity}

The Chinese Nationalist state on Taiwan went through a series of crises in the 1970s. In 1971, the Republic of China lost its UN seat, which was given to the People's Republic of China (PRC) - more than twenty years after its establishment in 1949. The UN General Assembly debated about the possibility of Taiwan retaining its seat in the General Assembly, with Tunisia and Saudi Arabia both proposing resolutions to that effect (Lin, 1986: 28-29). This proved to be impossible, however, due both to general sympathy to an anti-imperialist Chinas and Chiang Kai-shek's insistence that his regime represented all of China. Chiang Kai-shek died in 1975, to be succeeded as president by his son Chiang Ching-kuo. In 1978, the United States established diplomatic ties with the People's Republic of China and broke off ties with the Republic of China. As the Chinese Nationalist project to take back China began to lose legitimacy throughout the world and in Taiwan, Mainlanders and Native Taiwanese alike began demanding democratic reform. Even President Chiang Ching-kuo was forced to look to the people of Taiwan for political legitimacy. Unlike his father, he stressed his friendship with local people and encouraged Native Taiwanese participation in the Chinese Nationalist Party (Wachman, 1994: 153).

In December 1979, a pro-democracy march was held in Kaohsiung, only to be suppressed by the police. The trials of the main leaders, including Annette Lu who would eventually become vice-president in 2000 , were widely publicized in the media, bringing debates on Taiwanese independence into public discourse. For the first time in over thirty years, people started to question publicly if the Chinese Nationalist Party were not a foreign occupying force and Taiwan better off as an independent country. In dialectics familiar to Gramsci, Taiwanese counter-hegemonic nationalism began to emerge from Nationalist domination. Even in the early days, however, Taiwanese nationalists reached out to Mainlanders as members of a Taiwanese diaspora, showing that the movement was not just about ethnonationalism. As Annette Lu said in her 1979 rally speech:

It doesn't matter if you speak Chekiangese or Cantonese, or for that matter Uigur - in as much as we are all in the same boat, we should learn to love each other. Our bonds should be of the heart. Should we not take each other's hand and struggle together for the future of Taiwan? (International Committee for Human Rights in Taiwan, 1981: 45). wives of arrested activists often winning local elections as independent candidates. In 
1986, the dangwai candidates formed the Democratic Progressive Party, although opposition parties were still illegal. In 1987, Chiang Ching-kuo finally gave into the pressure of social activists and lifted martial law. In 1991, his successor Native Taiwanese Lee Teng-hui lifted the "temporary provisions" that had made it illegal to advocate Taiwanese independence.

During the presidency of Lee Teng-hui (1988-2000), the balance of power between Mainlanders and Native Taiwanese shifted dramatically. President Lee continued Chiang Ching-kuo's practices of Taiwanizing the party and the state. He went much further, however, by encouraging the indigenization (bentuhua) of official discourse. In what political scientist Stéphane Corcuff (2002b) calls the "symbolic dimension of democratization," statues of Chiang Kai-shek were removed from public squares, the national hymn was no longer required to be played before movies, and banknotes were redesigned with local Taiwanese rather than Chinese themes. By far the most controversial reform, however, was the introduction of Taiwan-centric curriculum in the school system, which drew the anger of Mainlander politicians. The Taiwanese language grew in prestige, a change visible in daily life, as well as in political campaigns when even Mainlander candidates had to give rally speeches in a language they once suppressed.

At the end of Lee Teng-hui's term, symbols of both the old and new regimes existed together, much like those of the pre- and post-apartheid eras in Nelson Mandela's South Africa in a policy of "Reconciliation" (Corcuff, 2002b: 97). Increasing indigenization of public life, however, made the Mainlanders seem more and more like outsiders in Taiwan. Although they had lost many of their old privileges, such as preference for employment, few were willing to look critically at their own past. With the elections of Native Taiwanese Chen Shui-bian of the DPP to the presidency in 2000 and 2004, ethnic relations continued to grow tense as both major camps used the theme of ethnicity to mobilize voters. It was in this context that Mainlander identity became relevant as a Diasporic identity, and specifically as what some (Schnapper, 2001: 17) call a "mobilized" one.

\section{Mainlander identity in the 2000s}

Amidst all of the changes, Mainlanders had to negotiate new identities in daily life. In order to distinguish themselves from the legacy of Chiang Kai-shek and a history of oppression, many began to portray their family histories as a diasporic journey from China to Taiwan. In an illustrative example, a Taipei coffee shop owner re-membered her family's past in a life history:

(My father) was different from other Mainlanders, since his circumstances were different from those that came over with the government. Most people can say that their fathers were in government or in business. But my father did neither. He simply came here as a tourist, and then had to stay behind. After that, his life was a tragedy. Why is that? Those Mainlanders who came over with the government had salaries, ranks in the government and free housing. The business people who came over had a lot of money. But my father had none of that. I grew up in a family without roots (Simon, 2003: 71).

Whereas Mainlanders once constructed their identities as Chinese living in the Republic of China, decolonization led to the construction of a new Taiwan around them, leading some to feel as if they were not accepted by local people. Many felt marginalized as the Taiwanese language became more prevalent in daily life, making 
them seem socially awkward and disadvantaged at work. Some felt as if they were materially disadvantaged as well. As a Native Taiwanese business class expanded, in fact, they did indeed create a business environment where Mainlanders were excluded, at least if they refused to learn Taiwanese. Ironically, the changing social situation was the result of earlier residential segregation, since Taiwanese farming families profited from rising real estate values and the city settlements of Mainlanders decayed into urban blight. The ethno-national sentiments of many Taiwanese, broadcast on radio talk shows and echoed in the daily conversation of many Native Taiwanese, made many Mainlanders feel like strangers in a country they had not chosen for themselves.

31 The Mainlander dilemma is that they can no longer return to China - most second- and third-generation Mainlanders were born in Taiwan and had never even been there. Yet they are not quite fully Taiwanese, as can be seen in the failure of Mainlander politicians to be accepted in an identity as "New Taiwanese" (Corcuff, 2002: 186-189). As one Mainlander told me about his identity dilemma both in Taiwan and while doing business in China: "In Taiwan, they say I am Chinese and don't accept me as fully Taiwanese; in China, they say I am Taiwanese and don't accept me as fully Chinese." This is a classic diaspora experience.

Because they fear Taiwanese ethnonationalism, Mainlanders are vulnerable to political mobilization. Although some individuals support Taiwanese nationalism, Mainlanders as a group tended to vote in 2000 and 2004 for the Chinese Nationalist Party and the People First Party, both of which promised to preserve the Republic of China as opposed to pursuing formal independence. Both parties promised to seek a closer relationship with China, including the possibility of re-unification if China were to become democratic. Republic of China nationalism became known as the "pan-blue" camp. This form of Chinese nationalism, although clearly different from that expressed in the People's Republic of China, led many Mainlanders to become hostile toward the "pan-green" parties that favor the formalization of Taiwanese independence.

Ethnic relations were especially tense during the events surrounding the 2004 presidential elections. On the eve of the election, DPP incumbent candidates Chen Shuibian and Annette $\mathrm{Lu}$ were campaigning in Chen's hometown of Tainan. As the candidates passed through the crowds in a jeep, two shots were fired, injuring Chen in the abdomen and $\mathrm{Lu}$ in the leg. Both flew back to Taipei that evening with minor injuries. After the election, when Chen was re-elected with a slim majority of $50.11 \%$, the pan-blue candidates Lien Chan and James Soong refused to concede defeat. Two years later, many Mainlanders still insisted that the assassination attempt had been staged by the DPP to garner sympathy votes. Some Mainlander intellectuals even began to argue that the DPP victory had ushered in an era of "green terror" designed to marginalize adherents of Chinese nationalism. Differences in Mainlanders and Native Taiwanese became especially visible in terms of both national identity and opinions for the future of Taiwan.

Public opinion surveys in Taiwan regularly ask the question: Are you Chinese (and not Taiwanese), Taiwanese (and not Chinese), or both Chinese and Taiwanese? Mainlanders clearly have stronger China consciousness than any other ethnic groups. In the 2005 survey by Decision Making Research for the Mainlander Taiwanese Association (Waisheng-Taiwanren Association, 2005), only 30.2\% of Mainlanders identified as Taiwanese, as opposed to $43.8 \%$ who identified as Chinese and $22.2 \%$ as both. By contrast, $68 \%$ of Hoklo identified as Taiwanese, as opposed to only $14.8 \%$ as Chinese and 
$12.4 \%$ as both (see Table 1). The fact that $66 \%$ of Mainlanders affirm Chineseness as at last part of their identities, as opposed to only $27.2 \%$ of Hoklo Taiwanese and $40.8 \%$ of Hakka Taiwanese, demonstrates that Mainlanders still tend to feel more Chinese than Taiwanese and that Taiwanese nationalist consciousness has taken strongest root among Native Taiwanese. It is worth noting, however, that nearly a third of Mainlanders identify as Taiwanese only. Although Mainlanders are still the most Chinese of all Taiwan residents, large numbers are accepting diasporic identity as both Chinese and Taiwanese. Many are even assimiliating to Taiwanese national identity.

Table 1: National identity in Taiwan according to ethnic identity ${ }^{1}$

Question: In Taiwan, some people consider themselves Taiwanese; others consider themselves Chinese. How do you consider yourself?

\begin{tabular}{|l|l|l|l|l|l|}
\hline & No. of cases & Taiwanese only & Chinese only & Both Taiwanese and Chinese & Other \\
\hline Hoklo & 793 & $68.0 \%$ & $14.8 \%$ & $12.4 \%$ & $4.9 \%$ \\
\hline Hakka & 71 & $53.5 \%$ & $22.5 \%$ & $18.3 \%$ & $5.6 \%$ \\
\hline Mainlanders & 162 & $30.2 \%$ & $43.8 \%$ & $22.2 \%$ & $3.7 \%$ \\
\hline
\end{tabular}

Source: Waisheng-Taiwanren Association and Decision Making Research, 2005: 88.

Ethnicity plays a strong role in how individuals envision the future of Taiwan and its relationship with China (see Table 2). Like all diasporic communities, a good number of Mainlanders aspire towards a "return," although usually not in a physical sense. For those Mainlanders who have returned to China after travel restrictions were lifted in 1985, in fact, the experience has often been disappointing as they found themselves alienated from long-lost relatives, or subjected to demands for money (see Simon, 2005: 125).

For many Mainlanders, the desired "return" has become more symbolic than physical, and is expressed as an emotional attachment to the Republic of China (not the People's Republic of China) and a rejection of formal Taiwanese independence; which would entail a permanent loss of Chinese identity. For this reason, support for the formal independence of Taiwan is much lower among Mainlanders than among other ethnic groups. In the same survey taken for the Mainlander Taiwanese Association, only 19.1\% of Mainlanders support independence, as opposed to $48.9 \%$ of Hoklo and $38.6 \%$ of Hakka respondants. Mainlanders are also the most likely to support unification, at $16.7 \%$ as opposed to $10.2 \%$ for Hoklo and $14.3 \%$ for Hakka respondents.

Table 2: Opinions on unification according to ethnic identity

Question: In terms of the future development of cross-straits relations, some people advocate unification and others advocate independence. Do you prefer unification or independence?

\begin{tabular}{|l|l|l|l|l|l|}
\hline Ethnic Group & No. of cases & Independence & Unification & Status Quo & Don't know \\
\hline
\end{tabular}




\begin{tabular}{|l|l|l|l|l|l|}
\hline Hoklo & 793 & $48.9 \%$ & $10.2 \%$ & $31.1 \%$ & $9.7 \%$ \\
\hline Hakka & 71 & $38.6 \%$ & $14.3 \%$ & $38.6 \%$ & $8.6 \%$ \\
\hline Mainlanders & 162 & $19.1 \%$ & $16.7 \%$ & $57.4 \%$ & $6.8 \%$ \\
\hline
\end{tabular}

Source: Waisheng-Taiwanren Association and Decision Making Research, 2005: 90.

Regardless of ethnicity, the number of individuals who support unification is relatively low because even most "pro-unification" individuals in Taiwan reject adherence to the present-day People's Republic of China. Some people believe that unification requires the precondition of democratization in China; and others think that independence is possible only if China renounces the threat of force against the island. In both cases, people who hold such opinions prefer to maintain the status quo. Most of the $57.4 \%$ of Mainlanders who want to maintain the status quo are either content with the existence of a de facto independent Republic of China limited to Taiwan, or are rejecting independence but holding off on unification until the time is right. Some Taiwanese also reject unification and are holding off for independence only when the conditions are right, but that logic is more common among Hoklo and Hakka Taiwanese.

There is also a difference in the way that members of different ethnic groups define the status quo. When asked if Taiwan and China are separate nations, or if Taiwan is part of China, only $42 \%$ of Mainlanders said that the two places are separate nations, as opposed to $67.1 \%$ of Hoko respondents. $38.3 \%$ of Mainlanders say that Taiwan is part of China, compared to only $16.3 \%$ of Hoklo respondents. The idea that Taiwan is part of China is derived from Chinese Nationalist Party ideology, as the party has long maintained that all of China belongs to the Republic of China and denied the legitimacy of Communist rule.

Table 3: Definitions of the Status Quo of Taiwan

41 Question: Some people say that Taiwan is part of China; there are also people who say that Taiwan and China are two independent nations. Which statement do you agree with?

\begin{tabular}{|l|l|l|l||l|}
\hline $\begin{array}{l}\text { Ethnic } \\
\text { Group }\end{array}$ & $\begin{array}{l}\text { No. of } \\
\text { cases }\end{array}$ & $\begin{array}{l}\text { Taiwan and China are two independent } \\
\text { nations }\end{array}$ & $\begin{array}{l}\text { Taiwan is part of } \\
\text { China }\end{array}$ & $\begin{array}{l}\text { Don't } \\
\text { know }\end{array}$ \\
\hline Hoklo & 793 & $67.1 \%$ & $16.3 \%$ & $16.6 \%$ \\
\hline Hakka & 71 & $62.9 \%$ & $27.1 \%$ & $10 \%$ \\
\hline Mainlanders & 162 & $42 \%$ & $38.3 \%$ & $19.8 \%$ \\
\hline
\end{tabular}

Source: Waisheng-Taiwanren Association and Decision Making Research, 2005: 82.

Chillingly, however, anthropological research shows that Mainlander Chinese nationalism is sometimes stronger than democratic values and a respect for difference. Some Mainlanders even welcomed China's 2005 Anti-Secession Law, which legislated 
"non-peaceful" means if Taiwan officially seceded from China, because they saw it as a way of forcing nationalistic Taiwanese to abandon the option of independence. While conducting research in an aboriginal village, I also heard one older Mainlander, retired from an influential community position, boast that, "we Mainlanders and aboriginal people will regain our normal status if (Chinese Nationalist candidate) Ma Ying-jeou wins the 2008 (presidential election)." This attitude illustrates the psychology of Mainlanders who have accepted neither Taiwanese national aspirations nor their new Diaspora status in democratizing Taiwan. This individual believes that Mainlanders naturally belong in positions of power over Native Taiwanese. If colonization for the colonized is a way of interacting with others "on terms not of their choosing" (Comaroff and Comaroff, 1991: 15), then so is decolonization for the colonizers. Some Mainlanders, including political leaders, are abandoning their colonial privileges for diasporic identities just as reluctantly as did whites in South Africa. The tensions of empire are yet to be resolved.

\section{Some comparisons in lieu of a conclusion}

It is tempting to make facile comparisons between Taiwan and South Africa, as did Wu Rwei-Ren in his argument that "the Mainlanders were in fact a powerful minority group not unlike the Afrikaaners in democratized South Africa" (Wu, 2001: 202). Although I ultimately disagree with $\mathrm{Wu}$ on the details, there are some interesting historical convergences that merit discussion. Europeans in South Africa and Han Chinese in Taiwan, for example, both moved to their new territories in response to the $17^{\text {th }}$ century activities of the Dutch East India Company.

It is important, however, to make a distinction between different kinds of colonial relationships, to recognize that a plurality of colonialisms (and decolonizations) can occur simultaneously, and to note that the process is not linear. The most important qualitative distinction between forms of colonialism is between settler colonialism and state colonialism, both of which create different diasporic identities. With this in mind, I think that there is little similarity between the Mainlanders of Taiwan and the Afrikaaners of South Africa. The Native Taiwanese are more similar structurally to the Afrikaaners; both groups having moved into their new territory from elsewhere 350 years ago and having accepted their new territory as their homeland. Like the Afrikaaners, who refer to their Dutch origin language as Afrikaaner, the Native Taiwanese call their Chinese language Taiwanese. The ethnic labels of Native Taiwanese and Afrikaaners also indicate the extent to which they are identified with their new territories and have ceased to be diasporas.

Native Taiwanese and Afrikaaners alike embraced nativist forms of nationalism, in spite of the fact that their historical origins lay outside of the national territories they claimed. In both cases, settler colonists do not neatly fit into the Safran's definition of diasporas. Although they share a historical experience of dispersal from their homeland, they do not share the other characteristics of diasporic communities including collective memories of that homeland, a belief that they are not accepted in their new land, a desire for return, support of their homeland, and a collective identity constructed around their place of origin. Instead, they are the nativist groups in relation to which the diaspora group is defined (Clifford, 1994). 

of diaspora in the form of the colonizers. This is the structural similarity between Mainlander Nationalist rule over Taiwan and British rule over South Africa. The competing nationalisms in Taiwan, therefore, resemble that of a defensive Afrikaaner nationalism faced with the "civilizing mission" of British administration in the $19^{\text {th }}$ and early $20^{\text {th }}$ centuries. The question then arises of which group in Taiwan most closely resembles the Black South Africans. It is surely not the "Native Taiwanese," but rather the Austronesian aborigines of the island. Like the blacks of South Africa, they lived on their native territory for millennia. They first lost control of their territory in western Taiwan when "Native Taiwanese" began settling in large numbers on the island in the seventeenth century (Brown 2004, Shepherd 1993). The arrival of the Republic of China in Taiwan did not represent decolonization to them any more than the arrival of the British in South Africa meant liberation for Black South Africans. It was merely the exchange of one colonial power for another.

Obviously, any structural comparison between South Africa and Taiwan quickly reaches its limits. Taiwan did experience some residential segregation in Taiwan in the sense that many Mainlanders lived in juancun (housing for the military and their dependents), and there was job discrimination against the Native Taiwanese in the beginning of Chinese Nationalist rule. Nonetheless, Taiwan never experienced the total separation and inhumane violence of Apartheid. There was an ideological colonization of Taiwanese consciousness, but largely because most Mainlanders honestly believed that Mainlanders, Native Taiwanese and even indigenous Austronesians were all Chinese in some essential way. Faced with the obvious linguistic and phenotypic differences between the former groups and the Austronesians, they made the ideological claim that the Austronesians had originated in China in prehistoric times (Ku, 2005: 106). To a certain degree, however, Mainlander attempts to teach Native Taiwanese and Austronesians to be Chinese were as well-intentioned as the activities of some Protestant missionaries in South Africa who tried to cross ethnic lines by appealing to a broader sense of humanity. In both cases, they believed that they were introducing the colonized subjects to a superior civilization.

e final analysis, however, any structural similarities between Taiwan and South Africa are less important than the theoretical insights that can be gained by juxtaposing the two cases. First, both cases demonstrate that ethnic identities are primarily relations between historically constituted groups rather than essentially defined objects. Like other forms of ethnicity, diaspora marks a relationship between groups. Second, the manipulation of ethnic relations can be an effective tool in governmentality. That process reinforces ethnic boundaries; albeit with consequences often unpredicted by those in power. Thirdly, in situations of colonialism or decolonization when new groups seize power, relationships between the groups are subject to struggle and negations. These processes are pluralistic and may happen simultaneously. Both processes are reversible, depending upon how the groups involved exercise political power. Fourthly, groups are defined as diasporas primarily in relationship to somebody else's national community. Diasporic identity is thus a part of the nationalist imaginary.

In Taiwan, the rise of Taiwanese nationalism made Mainlanders, combined with their own continued ties to an imagined Republic of China, into a diasporic community - the Chinese of Taiwan. Like the whites of South Africa, they became a diaspora without 
even moving because a new nation grew up around them. They are a diaspora, however, only to the extent that they accept the legitimacy of Taiwanese national aspirations. Their situation is very different from, for example, the Chinese diaspora the United States or France, because some of them resist the formation of a Taiwanese nation-state at all costs and insist that Taiwan must be Chinese forever. Few, if any, Chinese in the Vancouver or San Francisco would think of claiming Chinatown as part of China. The negotiation of diasporic identity thus happens also within larger negotiations of colonization and decolonization and not just within the experience of immigration. In Taiwan, those negotiations are much more complicated than elsewhere because an external power continues to mobilize ethnicity for its own imperial design.

Most importantly, I have chosen to compare Taiwan to South Africa rather than to other comparable colonial situations like Québec, which has been under English domination since the $18^{\text {th }}$ century, because I believe that the South African experience offers a limited space of hope. In post-Apartheid South Africa, the Truth and Reconciliation Commissions (TRCs) have made important steps toward ethnic reconciliation and a new constitution has laid the legal framework for a pluralistic, postmodern state. There have been problems in South Africa, as some whites have perceived the TRCs to be ANC-inspired witch hunts (McEachern, 2002: 22). In addition, ethnic mobilization continues to be an effective strategy in South African political campaigns, which casts doubt on the future of ethnic relations there (Davis, 2004).

At the very least, however, the TRCs have given South Africans what Nancy ScheperHughes calls a "good enough" truth, a narrative that puts different groups "on the same map rather than living in different nations across the road from each other" (Scheper-Hughes, 1998: 127). In Taiwan in 2005, Native Taiwanese President Chen Shuibian signed a "10-point consensus" with Mainlander opposition leader James Soong promising that the two parties would cooperate, among other things, on ethnic reconciliation. He also promised to include a clause in a new constitution for indigenous peoples, which would recognize their rights to tribal autonomy. Maybe these changes, like the TRCs of South Africa, can lead Taiwan towards a "heteronationalism" that "celebrates the right to difference as first principle" (Comaroff, 1996: 177). If white and black Africans can work together to build a new South Africa, surely there is opportunity for members of different ethnic groups to build a new Taiwan.

WU Rwei-Ren (2002) Toward a pragmatic nationalism: democratization and Taiwan's passive revolution, in Stéphane Corcuff Éd., Memories of the future: national identity issues and the search for a new Taiwan, Armonk, NY, M.E. Sharpe, pp. 196-218.

\section{BIBLIOGRAPHY}

ANDERSON Benedict (1991) Imagined communities: reflections on the origin and spread of nationalism, London, Verso Press, $224 \mathrm{p}$. 
ARRIGO Linda Gail (1998) Fifty years after 2-2-8: the lingering legacy of state terror in the consolidation of bourgeois democracy in Taiwan, Humboldt Journal of Social Relations, (23), pp. 47-69.

BARTH Fredrik, Éd. (1969) Ethnic groups and boundaries: the social organization of culture difference, Boston, Little and Brown, 153 p.

BROWN Melissa (2004) Is Taiwan Chinese? The Impact of Culture, Power, and Migration on Changing Identities, Stanford, Stanford University Press, $333 \mathrm{p}$.

CHANG Mau-kuei (2005) Waishengren: exploring Chinese (diaspora) nationalism in Taiwan, Invited lecture given in the Taiwan Seminar Series at the Asia-Pacific Research Centre, Stanford University, Palo Alto, USA, April 6.

CHEN Lung-chu and W.M. REISMAN (1972) Who owns Taiwan: a search for international title, Yale Law Journal, 81 (4), pp. 599-671.

CLIFFORD James (1994) Diasporas, Cultural Anthropology, 9 (3), pp. 302-338.

COMAROFF Jean and John L. COMAROFF (1989) The colonization of consciousness in South Africa, Economy and Society, 18 (3), pp. 267-296.

COMAROFF John L (1991) Of revelation and revolution: Christianity, colonialism, and consciousness in South Africa, Volume 1, Chicago, University of Chicago Press, 414 p.

COMAROFF John L (1989) Images of empire, contests of conscience: models of colonial domination in South Africa, American Ethnologist, 16 (4), pp. 661-685.

COMAROFF John L (1996) The nation-state in crisis and the rise of ethnonationalism, in Edwin N. Wilmsen et Patrick McAllister Éds., The politics of difference: ethnic premises in a world of power, Chicago, University of Chicago Press, pp. 162-183.

COMAROFF John L (1998) Reflections on the colonial state, in South Africa and elsewhere: factions, fragments, facts and fictions, Social Identities, 4 (3), pp. 321-361.

COOPER Frederick and Ann L. STOLER (ed.) (1989) Tensions of empire, special section in American Ethnologist 16 (4).

CORCUFF Stéphane, Éd. (2002) Memories of the future: national identity issues and the search for a new Taiwan, Armonk, NY, M.E. Sharpe, 285 p.

CRAPANZANO Vincent (1986) Waiting: the whites of South Africa, New York, Vintage Books, $361 \mathrm{p}$.

DAVIS Gavin (2004) Proportional representation and racial campaigning in South Africa, Nationalism and Ethnic Politics, 10 (2), pp. 297-324.

DIRKS Nicholas B. Éd. (1992) Colonialism and culture, Ann Arbor, University of Michigan Press, $402 \mathrm{p}$.

EDMONDSON Robert (2002) The February 28 incident and national identity, in Stéphane Corcuff Éd., Memories of the future: national identity issues and the search for a new Taiwan, Armonk, NY, M.E. Sharpe, pp. 25-46.

ELBAZ Mikhaël and HELLY Denise (1995) Modernité et postmodernité des identités nationales, Anthropologie et Sociétés, 19 (3), pp. 15-35.

FANON Franz (1967) Black skin, white masks, translated by Charles Lam Markmann, New York, Grove Press, $232 \mathrm{p}$. 
GATES Hill (1981) Ethnicity and social class, in Emily A. Martin et Hill Gates Éds., The anthropology of Taiwanese society, Stanford, Stanford University Press, pp. 241-281.

GREENHALGH Susan (1994) De-orientalizing the chinese family firm, American Ethnologist, 21 (4), pp. 746-775.

HSIUNG Ping-Chun (1996) Living rooms as factories: class, gender, and the satellite factory system in Taiwan, Philadelphia, Temple University Press, $182 \mathrm{p}$.

INTERNATIONAL COMMITTEE FOR HUMAN RIGHTS IN TAIWAN (1981) The Kaohsiung tapes, Seattle, International Committee for Human Rights in Taiwan, [http://www.taiwandc.org/kao-tapes.pdf, last accessed April 19, 2005].

KERR George (1965) Formosa betrayed, Boston, Houghton Mifflin Company, 514 p.KU, Kun-hui (2005) Rights to recognition: Minority/indigenous politics in the emerging Taiwanese nationalism, Social Analysis 49 (2), pp. 99-121.

LAI Tse-han, Ramon MYERS, and Wei WOU (1991) A tragic beginning: the Taiwan uprising of February 28, 1947, Stanford, Stanford University Press, 273 p.

LIN Hsin-ho (1986) Der völkerrechtliche Status der Republik China (Taiwan) nach dem Ausschluss der nationalchinesischen Regierung aus den Vereinten Nationen: Dargestellt im Licht der internationalen Praxis, Ebelsbach, Verlag Rolf Gremer, 353 p.

LIN Tsung-yi (1998) An introduction to 2-28 tragedy in Taiwan: for world citizens, Taipei, Taiwan Renaissance Foundation Press, 303 p.

MCEACHERN Charmaine (2002) Narratives of nation: media, memory and representation in the making of the new South Africa, New York, Nova Science Publishers, 166 p.

MEISNER Maurice (1963) The development of Formosan nationalism, China Quarterly, (15), pp. 91-106. MENDEL Douglas (1970) The politics of Formosan nationalism, Berkeley, University of California Press, $315 \mathrm{p}$.

MORRIS Andrew D. (2004) Taiwan's history: an introduction, in David K. Jordan, Andrew D. Morris, and Marc L. Moskowitz Éds., The minor arts of daily life: popular culture in Taiwan, Honolulu, University of Hawaii Press, pp. 3-31.

MURRAY Stephen O. and Keelung HONG (1994) Taiwanese culture, Taiwanese society: a critical review of social science research done on Taiwan, Lanham, MD, University Press of America, $244 \mathrm{p}$.

PHILIPS Steven (1999) Between assimilation and independence: Taiwanese political aspirations under Nationalist Chinese rule, 1945-1948, in Murray A. Rubinstein Éd., Taiwan: a new history, Armonk, NY, M.E. Sharpe, pp. 275-319.

PHILIPS Steven (2003) Between assimilation and independence: the Taiwanese encounter Nationalist China, 1945-1950, Stanford, Stanford University Press, 256 p.

SAFRAN William (1991) Diasporas in modern societies: myths of homeland and return, Diaspora, 1 (1), pp. 83-99.

SCHEPER-HUGHES Nancy (1998) Undoing: social suffering and the politics of remorse in the new South Africa, Social Justice, 25 (4), pp. 114-142.

SCHNAPPER Dominique (2001) De l'État-nation au monde transnational. Du sens et de l'utilité du concept de diaspora, Revue Européenne des Migrations Internationales, 17 (2), pp. 9-36.

SHEPHERD John (1993) Statecraft and Political Economy on the Taiwan Frontier, 1600-1800, Stanford, Stanford University Press, 596 p. 
SIMON Scott (2003a) Contesting Formosa: tragic remembrance, urban space, and national identity in Taipak, Identities: Global Studies in Culture and Power, 10 (1), pp. 109-131.

SHEPHERD John (2003b) Sweet and sour: life-worlds of Taipei women entrepreneurs, Lanham, MD, Rowman \& Littlefield, 246 p.

SHEPHERD John (2005) Tanners of Taiwan: life strategies and national culture, Boulder, Colorado, Westview Press, $172 \mathrm{p}$.

WACHMAN Alan M (1994) Taiwan: national identity and democratization, Armonk, NY, M.E. Sharpe, $294 \mathrm{p}$.

WAISHENG TAIWANREN ASSOCIATION AND DECISION MAKING RESEARCH (2005) Ethnic relations: public survey report, Taipei, Decision Making Research, $91 \mathrm{p}$.

WANG Fu-chang (2005) Why did the DPP win Taiwan's 2004 presidential election? An ethnic politics interpretation, Pacific Affairs, 77 (4), pp. 691-696.

WANG Horng-luen (2004) Regulating transnational flows of people: an institutional analysis of passports and visas as a regime of mobility, Identities: Global Studies in Culture and Power, 11 (3), pp. 351-376.

\section{NOTES}

1. This survey, conducted by the Decision-Making Research Company, January 28-29, 2005, includes residents of the Taipei Metropolitan Area. $\mathrm{N}=1,042(+-3.1 \%, \mathrm{p}<.05)$. The three aboriginal responses were eliminated from the table because the sample is too small to be meaningful. Thanks to Chang Mau-kuei, Academia Sinica, for providing the data.

\section{ABSTRACTS}

This paper looks at the construction of diasporic identity in Taiwan among the Mainlanders who arrived with Chiang Kai-shek at the conclusion of World War II. In the early decades of Chinese Nationalist rule, which many Taiwanese perceived as colonial rule, ethnic differences between Mainlanders and Native Taiwanese were constructed through state violence, political oppression, and discrimination in favour of Mainlanders. With democratization, the numerically dominant Native Taiwanese began to assert Taiwanese nationalism and Mainlanders started to question their identity. Some adopted a diasporic identity as Chinese in Taiwan while others resisted change. Mainlander diasporic identity is constructed primarily in relationship to the nativist nationalism of the Native Taiwanese, but also to the autochtonous identity of Taiwan's indigenous tribes. Diaspora identity is thus relevant not only in situations of immigration, but also in processes of colonialism and subsequent decolonization.

Cet article traite de la construction de l'identité diasporique des Chinois du continent arrivés avec Chiang Kai-shek à Taiwan à la fin de la Deuxième Guerre mondiale. Pendant les premières décennies de l'autorité nationaliste chinoise, que beaucoup de Taiwanais considéraient comme une autorité de type colonial, les différences ethniques entre autochtones taiwanais et Chinois du 
continent se construisirent à travers la violence d'État, l'oppression politique et la discrimination. Avec le processus de démocratisation, les indigènes taiwanais, majoritaires en nombre, commencèrent à affirmer un nationalisme taiwanais, et les Chinois du continent commencèrent à questionner leur identité. Certains d'entre eux adoptèrent une identité diasporique comme Chinois de Taiwan, alors que d'autres résistèrent au changement. L'identité diasporique des Chinois du continent est construite essentiellement en rapport avec le nationalisme indigène des autochtones taiwanais, mais aussi avec l'identité indigène des tribus autochtones de Taiwan. L'article montre que l'identité diasporique est pertinente non seulement dans les situations d'immigration, mais aussi dans les processus de colonisation et de décolonisation.

Este articulo trata de la construcción de la identidad "diaspórica" de los chinos del continente llegados a Taiwán después la Segunda Guerra Mundial con Chiang Kai-shek. Durante las primeras décadas de la autoridad nacionalista china, que muchos taiwaneses consideraban como una autoridad de tipo colonial, las diferencias étnicas entre taiwaneses autóctonos y chinos del continente se construyeron a través de la violencia de estado, de la opresión política y de la discriminación. Con el proceso de democratización, los indígenas taiwaneses, mayoritarios, comenzaron a afirmar un nacionalismo taiwanés. Por su parte, los chinos del continente empezaron a cuestionar su propia identidad: ciertos de entre ellos adoptaron una identidad "diaspórica" reivindicándose a si mismos como chinos de Taiwán mientras que otros resistieron al cambio. La identidad "diaspórica" de los chinos del continente se construye esencialmente en relación con el nacionalismo indígena de los taiwaneses autóctonos y con la identidad indígena de las tribus autóctonas de Taiwán. El artículo muestra que la identidad "diaspórica" no sólo es pertinente en situaciones de inmigración sino también en procesos de colonización y de descolonización.

\section{INDEX}

Mots-clés: changement culturel, Chinois, colonisation, diaspora, identité nationale Geographical index: Taiwan

\section{AUTHOR}

\section{SIMON SCOTT}

Associate Professor, Department of Sociology, University of Ottawa, 550, Cumberland, Ottawa, ON K1H 8L1 Canada, ssimon@uottawa.ca 